\title{
Rola brył martwego lodu w morfogenezie Kotliny Grudziądzkiej i Basenu Świeckiego - formy rzeźby i osady
}

\author{
Role of dead ice in morphogenesis of Grudziądz Basin and Świecie Basin - \\ landforms and sediments
}

\author{
Jarosław Kordowski \\ Instytut Geografii i Przestrzennego Zagospodarowania, Polska Akademia Nauk, Toruń, jarek@geopan.torun.pl
}

Zarys treści: W artykule przedstawiono przegląd dowodów na obecność brył martwego lodu w Dolinie Dolnej Wisły między Bydgoszczą i Grudziądzem. Omówiono oddziaływanie spływów gliniastych w dnie doliny, form szczelinowych, teras kemowych, zagłębień wytopiskowych, ostańców terasowych, rynien subglacjalnych reprodukowanych w osadach fluwialnych i fluwioglacjalnych oraz zastoisk „włożonych” we wcześniej ukształtowaną formę dolinną na morfogenezę doliny. Na podstawie wyników badań sformułowano tezę, że dolina Wisły w omawianym fragmencie była w większości uformowana jeszcze przed ostatnim nasunięciem lądolodu w fazie poznańskiej górnego vistulianu. Proces kształtowania systemu terasowego musiał mieć szybki przebieg, szybszy niż tempo wytapiania brył martwego lodu.

Slowa kluczowe: bryły martwego lodu, Dolina Dolnej Wisły

\begin{abstract}
In the paper there are presented proofs for existence of dead ice in the Vistula valley between Bydgoszcz and Grudziądz. There is discussed the significance of specific landforms and sediments for the valley morphogenesis among them of till debrites on the valley floor, forms of ice crevasses infilling, kame terraces, terrace remnants, subglacial channels reproduced within fluvial and glacifluvial sediments and proglacial ice dammed lakes embedded in the river valley. The material presented inclines to suggestion that lower Vistula valley, in the discussed area, was formed in broad outline already before the last glacial advance during the main/upper vistulian stadial. The terraces system had developed very quickly, much quicker than the rate of dead ice disintegration.
\end{abstract}

Key words: dead-ice blocks, Lower Vistula Valley

\section{Wstęp}

Dolinę Dolnej Wisły, na podstawie systemu odpływu, jaki funkcjonował w późnym glacjale, można podzielić na dwa fragmenty. Fragment północny położony jest poniżej przełomu Wisły w Fordonie, zaś południowy przebiega od Fordonu do linii maksymalnego zasięgu ostatniego zlodowacenia. Odcinek ten jest powiązany z systemem pradolin odprowadzających wody z lądolodu oraz wody rzeczne płynące z południa poprzez Pradolinę Warszawsko-berlińską, pradoliny kujawskie i Pradolinę Toruńsko-Eberswaldzką (Niewiarowski 1968, Wiśniewski 1990, Molewski 2007, Weckwerth 2010, 2013). Na odcinku północnym, między Fordonem a Żuławami, nie było możliwości wykształcenia równoleżnikowych pradolin. Odpływ mógł odbywać się tylko na południe lub na północ. Taka sytuacja paleogeograficzna miała swoje konsekwencje w wykształceniu rzeźby i osadów dolinnych. Istnieją dowody, że kształtowanie się obecnego systemu terasowego następowało $\mathrm{w}$ warunkach zalegania rozległych płatów i brył martwego lodu (Drozdowski 1974, Kordowski 2001, 2013).

Na podstawie wyników badań pruskiej służby geologicznej uważano (Sonntag 1919), że w dolinie Wisły poniżej Fordonu, w miarę cofania się czoła lądolodu, powstawały liczne, zmienne zastoiska wód proglacjalnych. 
Jedno z większych zastoisk miało znajdować się w okolicach Grudziądza. Należy mieć na uwadze, że poglądy te prezentowane były na początku XX w., kiedy wiele pojęć geologii glacjalnej nie było jeszcze dobrze zdefiniowanych i ugruntowanych.

Badania przeprowadzone przez Galona (1934) wskazały na obecność na analizowanym odcinku doliny licznych teras, szczególnie w pobliżu kępy Górnej Grupy. Są one położone na wysokościach 61-59 m n.p.m. (terasa Vc), 55-54 m n.p.m. (terasa Vb), 45 m n.p.m. (terasa IV), 38-35 m n.p.m. (terasa III), 31-26 m n.p.m. (terasa II) oraz na wysokości 26-22 m n.p.m. (dwa poziomy równi- ny zalewowej Ia i Ib). Według Galona (1934, 1953, 1968) wymienione terasy można łączyć genetycznie $\mathrm{z}$ terasami występującymi na obszarze Pradoliny Toruńsko-Eberswaldzkiej i w dolinie Brdy. Ich numeracja w dolinie Wisły uległa modyfikacji (ryc. 1, terasa IX - $61 \mathrm{~m}$ n.p.m., VIII - 55 m n.p.m., VII - 50 m n.p.m., VI - 48 m n.p.m., V - 38 m n.p.m., IV - 30 m n.p.m., III - 27 m n.p.m., II - 25 m n.p.m. oraz terasa I - 22 m n.p.m.). Późniejsze wyniki badań Drozdowskiego $(1974,1979)$ uszczegółowiły przestrzenny układ systemu terasowego w Kotlinie Grudziądzkiej. Na podstawie analogii do wyników badań w Pradolinie Toruńsko-Eberswaldzkiej (Galon 1961)

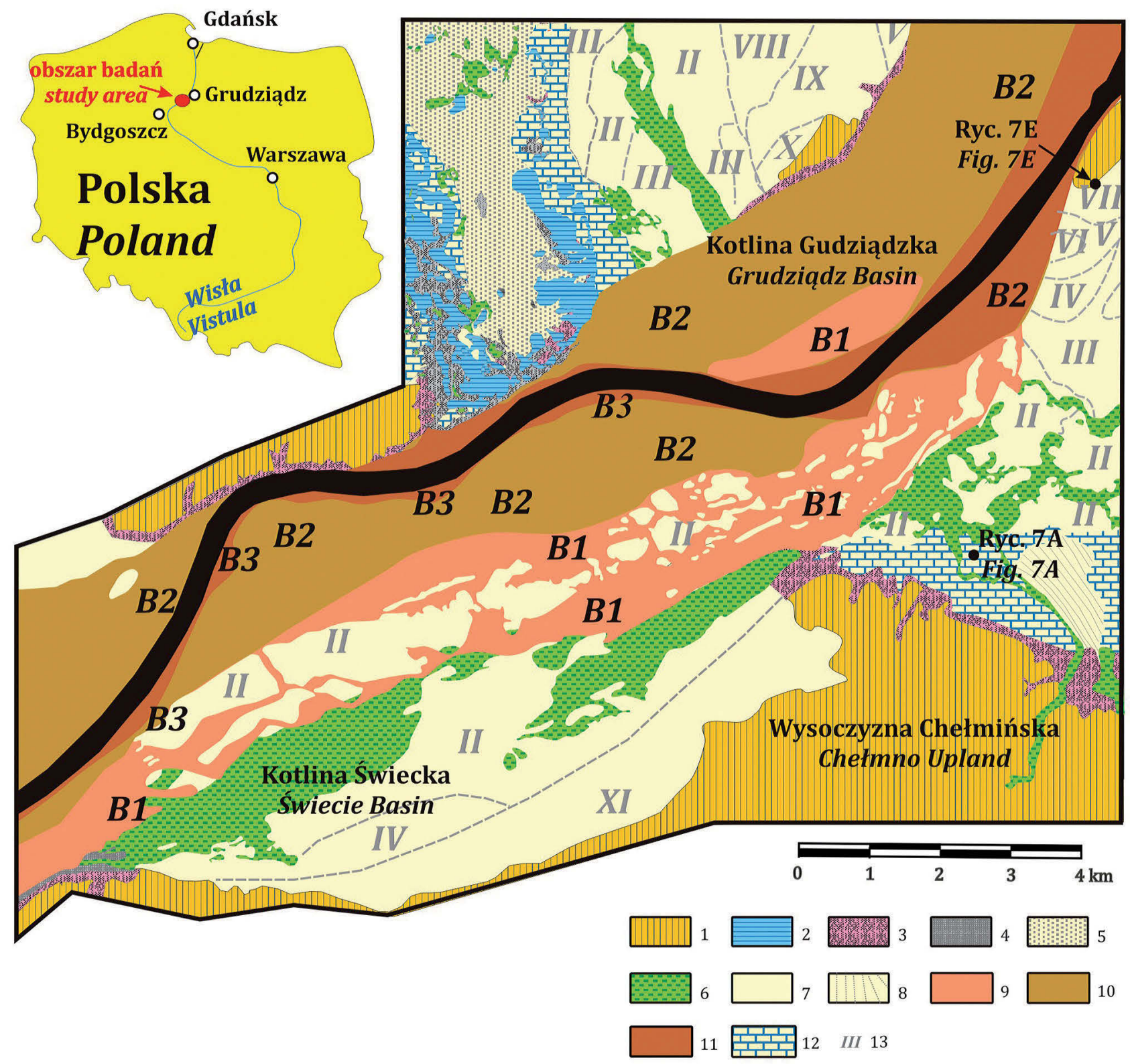

Ryc. 1. Szkic geomorfologiczny Doliny Dolnej Wisły na południe od Grudziądza

1 - wysoczyzny morenowe, 2 - dna zastoisk, 3 - długie stoki, 4 - strefy akumulacji deluwiów, 5 - równiny sandrowe, 6 - równiny biogeniczne, 7 - terasy fluwioglacjalne i fluwialne, 8 - stożki napływowe, poziomy równiny zalewowej: $9-\mathrm{B} 1,10-\mathrm{B} 2,11-\mathrm{B} 3,12$ - kemowe terasy późnoglacjalne z dużym udziałem osadów spływowych, częściowo przewiane, 13 - numery teras

Fig. 1. Geomorphological sketch of the Vistula valley between Górsk and Grudziądz

1 - till plains, 2 - bottoms of ice-dammed lakes, 3 - long slopes, 4 - zones of colluvial accumulation, 5 - outwash plains, 6 - biogenic plains, 7 - fluvioglacial and fluvial terraces, 8 - proluvial fans, floodplain levels: 9 - B1, 10 - B2, 11 - B3, 12 - Late Glacial kame terraces, partly overblown, 13 - terraces numbers 
przyjęty był pogląd o bifurkacji Wisły w rejonie Bydgoszczy (Fordonu) w poziomach IX-VI, według którego część wód Wisły kierowała się do Pradoliny Noteci-Warty, a część na północ do Doliny Fordońskiej. Terasy niższe miały rozwijać się już tylko przy odpływie wód skierowanym na północ.

Zdaniem Weckwertha (2006) terasę VI należy rozdzielić na poziom wyższy (VIa) i niższy (VIb). Autor ten zawęża okres bifurkacji Wisły do czasu przepływu tej rzeki w poziomach teras VIII-VIa. Według Weckwertha (2006) poziom VIa związany był zarówno z odpływem w kierunku północnym, jak i zachodnim, natomiast w poziomie VIb Wisła płynęła wyłącznie w kierunku północnym.

Koncepcja rozwoju rzeźby fluwialnej Doliny Dolnej Wisły była modyfikowana przez Drozdowskiego (1974, 1979, 1982), który stwierdził na zboczach doliny Wisły terasy kemowe w rejonie Skarszew i w okolicach Świętego w Kotlinie Grudziądzkiej. Zdaniem Drozdowskiego $(1974,1979,1982)$ Kotlina Grudziądzka powstała w wyniku erozji glacjalnej lądolodu w czasie stadiału świecia zlodowacenia wisły. Bryły martwego lodu miały przetrwać pod osłoną osadów ablacyjnych do czasu następnego nasunięcia lądolodu w stadiale głównym. Po recesji tego lądolodu kotlina została odpreparowana u schyłku późnego glacjału, o czym świadczą wyniki datowania radiowęglowego osadów biogenicznych wypełniających rynnę fletnowską i rynnę Jeziora Rudnickiego (Berglund, Drozdowski 1976). Wyniki tych badań wskazują na to, że wszystkie terasy starsze od równiny zalewowej powstały już przed allerødem (Berglund, Drozdowski 1976, Drozdowski 1982, Niewiarowski 1987). Spostrzeżenia Drozdowskiego w późniejszym czasie zostały uwzględnione w trakcie badań prowadzonych w ramach realizacji arkuszy szczegółowej mapy geologicznej Polski (Butrymowicz 1981, Maksiak 1983) oraz znalazły potwierdzenie w wynikach badań autora w Basenie Unisławskim (Kordowski 2001), Basenie Świeckim (Kordowski 2005) i Kotlinie Grudziądzkiej (Kordowski 2013) (ryc. 1).

Celem artykułu jest przedstawienie morfologicznych i sedymentologicznych dowodów na obecność brył martwego lodu w czasie kształtowania się Doliny Dolnej Wisły między Bydgoszczą i Grudziądzem, w okresie recesji ostatniego zlodowacenia.

\section{Metody badań}

Przedstawione wyniki badań opierają się na kartowaniu geologicznym i geomorfologicznym prowadzonym od kilkunastu lat w Dolinie Fordońskiej. Obejmowało ono badania sedymentologiczne osadów na stanowiskach kluczowych, a w tym analizy struktur sedymentacyjnych, elementów kierunkowych tych struktur oraz analizy zmienności uziarnienia. Próbki do analiz granulometrycznych pobierane były co $5 \mathrm{~cm}$ na całej długości profili. W czasie badań laboratoryjnych poddano je analizie uziarnienia metodą kombinowaną. Dla frakcji powyżej $0,1 \mathrm{~mm}$ stosowano metodę sitową, zaś dla frakcji poni- żej 0,1 mm osad analizowano na laserowym analizatorze cząstek Analysette 22 Economy. Wyniki analizy rozkładu uziarnienia osadów przedstawiono za pomocą zmienności wartości Mz, czyli średniej średnicy ziarna według reguły stosowanej przez Folka i Warda (1957). Informacje pozyskane z odsłonięć uzupełnione były gęstą siatką wierceń ręcznych w ilości co najmniej kilkunastu na każdym kilometrze kwadratowym kartowanego obszaru.

\section{Formy i osady świadczące o obecności bryl martwego lodu}

\section{Wstęgi spływów gliniastych w dnie doliny}

Stwierdzone w dnie Basenu Świeckiego wstęgi spływów gliniastych są formami o długości do $4 \mathrm{~km}$ i szerokości do 2,5 km (ryc. 2). Łączna miąższość glin i piasków sięga $\mathrm{w}$ ich obrębie do $3 \mathrm{~m}$, przeciętnie jest to około $1,5 \mathrm{~m}$. Szczegółowo formy te omówione zostały w pracy Kordowskiego (2005). Czasem ich depozycji musiał być okres późnoglacjalny lub wczesnoholoceński, kiedy w rejonie Polski północnej następowała degradacja wieloletniej zmarzliny. Na Pojezierzu Starogardzkim datowana jest ona na okres do preboreału (Błaszkiewicz 2005, Kordowski $\mathrm{i}$ in. ten tom). Jeśli do dziś występują wstęgi spływów gliniastych, to można przyjąć, że fragmenty dna doliny przez nie zajęte nie były kształtowane przez migrację koryta Wisły w holocenie (ryc. 2, zasięg linii przerywanej). Ustalony w ten sposób pas występowania holoceńskich, korytowych osadów równiny zalewowej można szacować na 2,5-3,5 km szerokości, czyli około 5-krotność szerokości koryta z okresu przed regulacją w XIX w.

\section{Ozy}

Ozy nie są zjawiskiem wyjątkowym w dolinie Wisły. Zostały one opisane w Kotlinie Płockiej m.in. przez Skompskiego (1969). W przypadku Kotliny Grudziądzkiej formy te występują już w poziomie wysokościowym odpowiadającym pierwszej terasie nadzalewowej (I) (ryc. 2, 3).

Do form szczelinowych zaliczono wał w okolicy Gogolina (ryc. 3). Składa się on z dwu części, większej (o długości $3 \mathrm{~km}$ i szerokości 100-150 m) oraz mniejszej (o długości $500 \mathrm{~m}$ i szerokości ok. $50 \mathrm{~m}$ ). Prawdopodobnie pierwotna długość omawianej formy była większa, ponieważ od strony wschodniej jest ona ukryta pod osadami stożka napływowego w okolicy Wałdowa Szlacheckiego. Większa jego część zbudowana jest z piasków drobnoziarnistych, co udało się stwierdzić za pomocą wierceń na wierzchołku i stoku formy. W mniejszym wale udokumentowano piaski drobno- i średnioziarniste o warstwowaniu horyzontalnym, ze sporadycznie występującymi warstewkami gliniastymi (ryc. 4, odsłonięcie 5).

Depozycja ozu w Gogolinie, ze względu na jego bardzo prostolinijny przebieg i obecność cienkich wkładek diamiktonowych, musiała zachodzić w szczelinie lodo- 


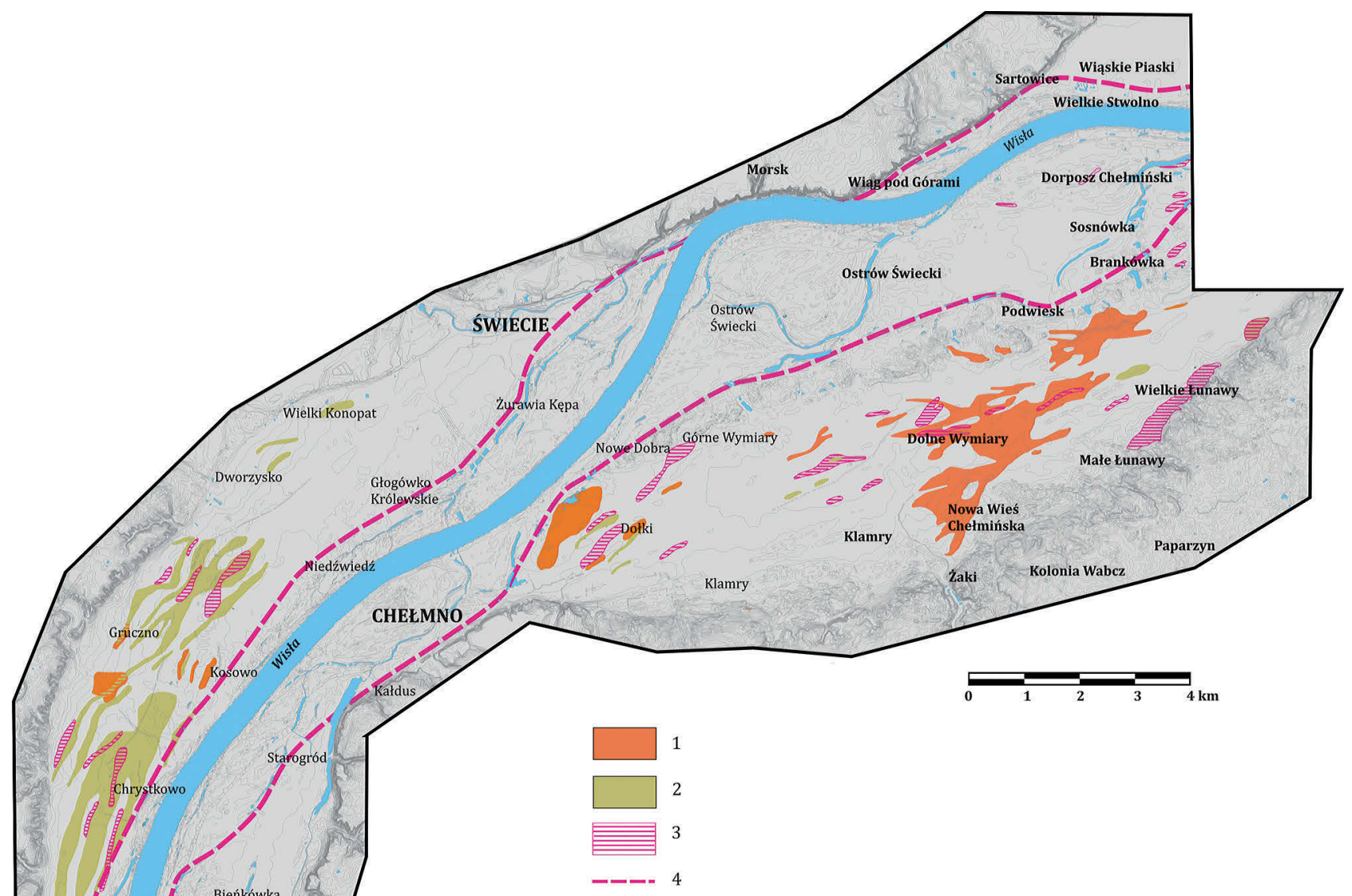

Bieńkówka 5

Ryc. 2. Mapa występowania osadów spływów gliniastych w Kotlinie Świeckiej

1 - zasięg spływów gliniastych, 2 - wytrącenia węglanowe, 3 - wytrącenia żelaziste, 4 - przypuszczalny zasięg holoceńskich osadów korytowych równiny zalewowej, 5 - nazwy miejscowości

Fig. 2. Map of debrites in Świecie Basin

1 - localities, 2 - extent of the debrites, 3 - carbonaceous precipitates, 4 - iron precipitates, 5 - supposed extent of Holocene channel floodplain sediments

wej z jednostajnym przepływem wód, ponieważ nie zaznaczają się zmiany struktur sedymentacyjnych, a wielkość średniej średnicy ziarna pozostaje dość podobna w całym obserwowanym profilu odsłonięcia. Obecność warstwowań horyzontalnych świadczy o dominacji przepływów warstwowych w warunkach górnego płaskiego dna (Zieliński 1998).

\section{Terasy kemowe}

Terasy kemowe są powszechnym elementem rzeźby obszarów zlodowaconych. Definiowane są jako formy kształtujące się między zboczem wzniesienia lub doliny a czołem lodowca, które wymusza przepływ wód roztopowych wzdłuż krawędzi morfologicznych oraz równolegle do krawędzi lodowca (Flint 1971, Klimaszewski 1981). Czasami, w celu podkreślenia pokrewieństwa do kemów, nadaję się im nazwę kemów lateralnych (Karczewski 1971). Na terenach nizinnych formy te są częste na stokach i w dnach rynien subglacjalnych, zwłaszcza u ich wylotu do dolin rzecznych, a także w samych dolinach, m.in. w dolinie Wisły (Skompski 1969, Chormański, Mycielska-Dowgiałło 1996). Ze względu na rodzaj występu- jących w nich osadów często stosowany jest podział na kemy glacilimniczne, kemy z dominacją osadów jezior glacjalnych i glacifluwialne $\mathrm{z}$ udokumentowanym przepływem wód roztopowych (Niewiarowski 1961, Bitinas i in. 2004). W praktyce większość teras kemowych ma jednak genezę bardziej złożoną (Niewiarowski 1961).

System teras kemowych w południowej części Kotliny Grudziądzkiej składa się z następujących poziomów morfologicznych (ryc. 3, 5): J - wysokość 70-72 m n.p.m., szerokość 200-400 m, G - wysokość 40-60 m n.p.m., szerokość 40-400 m, przeciętnie $100 \mathrm{~m}, \mathrm{D}$ - wysokość 35-40 m n.p.m., szerokość około 800-1500 m, A - poziom najniższy, wysokość 30-35 m n.p.m., szerokość ponad $1 \mathrm{~km}$.

To, że w Kotlinie Grudziądzkiej mamy do czynienia z terasami kemowymi a nie terasami fluwioglacjalnymi bądź fluwialnymi, wynika z analizy ich litologii, zwłaszcza obecności struktur osuwiskowych, rytmitów mułkowych, struktur kotwiczenia brył lodowych, warstw żwirowych związanych ze spływami zbiorników sedymentacyjnych (ryc. 4, odsłonięcie 1) (Kordowski 2013) i klastów gliniastych tworzących dump structures (Kordowski i in. 2012). Wymienione struktury i osady zostały 

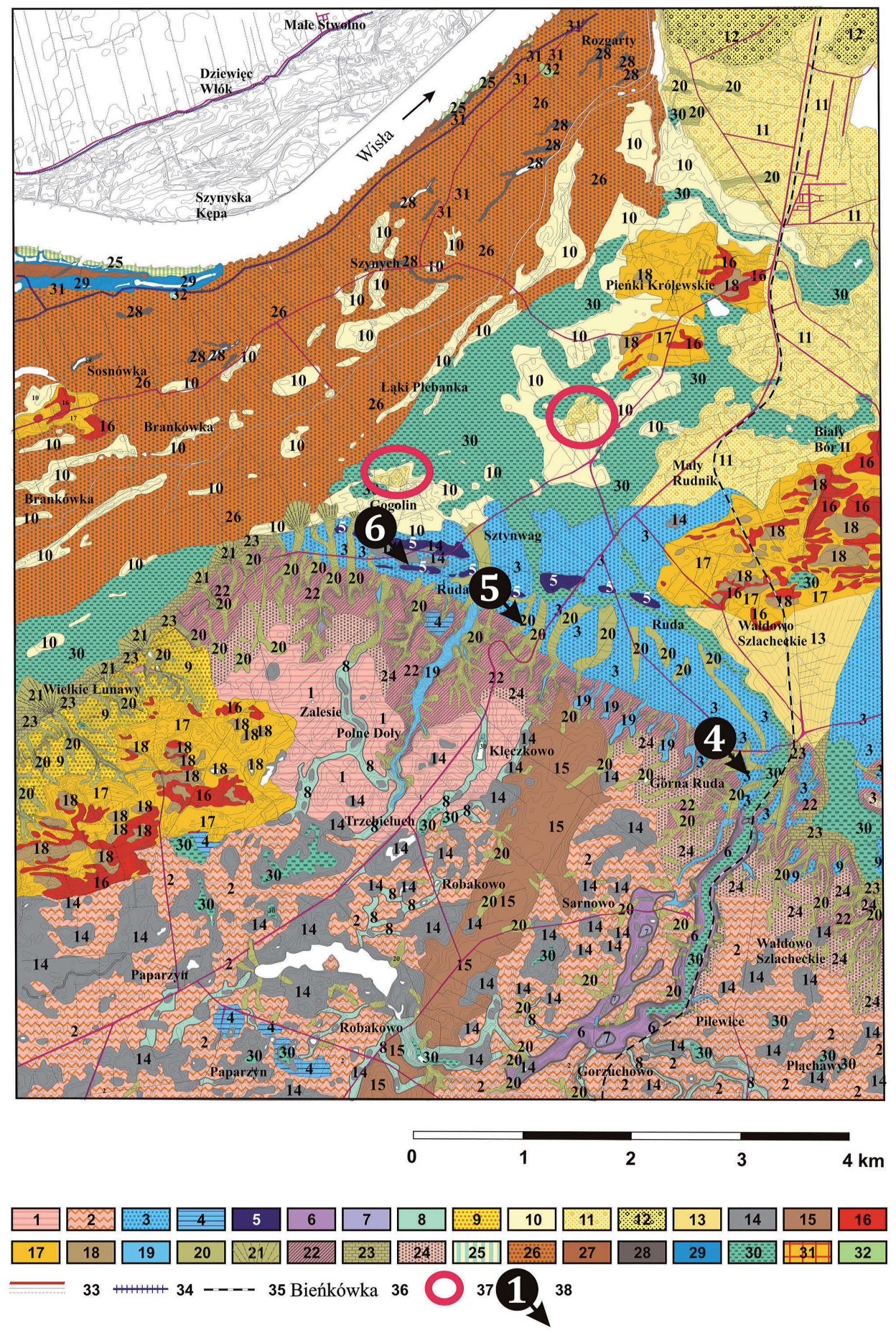

Ryc. 3. Mapa geomorfologiczna południowej części Kotliny Grudziądzkiej

1 - wysoczyzna morenowa płaska, 2 - wysoczyzna morenowa falista, 3 - terasy kemowe, niskie, 4 - kemy i strefy akumulacji glacjolimnicznej bez wyraźnych krawędzi morfologicznych, 5 - ozy, 6 - rynny subglacjalne, 7 - wzniesienia i progi w dnach rynien subglacjalnych, 8 - dolinki wód roztopowych, 9 - terasy kemowe, wyższe, 10 - terasa I, 11 - terasa II, 12 - terasa III, 13 - stożki napływowe, 14 - wytopiska, 15 - megadrumliny(?), 16 - wydmy, 17 - równiny piasków pokrywowych, 18 - niecki deflacyjne, 19 - młode wcięcia erozyjne, 20 - niecki i zagłębienia powstałe wskutek denudacji, 21 - stożki proluwialne, 22 - długie stoki, 23 - strefa agradacji, 24 - strefa degradacji, 25 - wały przykorytowe, 26 - wyższy poziom równiny zalewowej, 27 - niższy poziom równiny zalewowej, 28 - krewasy, 29 - opuszczone koryta rzeczne, 30 - równiny biogeniczne, 31 - nasypy, 32 - wykopy, 33 - drogi, 34 - wały przeciwpowodziowe, 35 - linie kolejowe, 36 - nazwy miejscowości, 37 - ostańce terasowe, 38 - odsłonięcia omawiane w tekście

Fig. 3. Geomorphological map of the southern part of Grudziądz Basin

1 - flat till plains, 2 - undulating till plains, 3 - kame terraces, lower levels, 4 - kames and zones of glacilimnic accumulation without distinct morphological edges, 5 - eskers, 6 - subglacial channels, 7 - elevations and thresholds on the floors of subglacial channels, 8 - small meltwater routes, 9 -kame terraces, higher levels, 10 - terrace I, 11 - terrace II, 12 - terrace III, 13 - proluvial fans, 14 - kettle holes, 15 - megadrumlins(?), 16 - dunes, 17 - eolian sands covers, 18 - deflation mounds, 19 - young incisions, 20 - moulds and hollows of denudation origin, 21 - proluvial fans, 22 - long slopes, 23 aggradation zone, 24 - degradation zone, 25 - levees, 26 - upper floodplain level, 27 - lower floodplain level, 28 - crevasses, 29 - abandoned river channels, 30 - biogenic plains, 31 - earthwork, 32 - artificial pits, 33 - roads, 34 - embankments, 35 - railways, 36 - localities names, 37 - terraces remnants, 38 - outcrops discussed in the text 


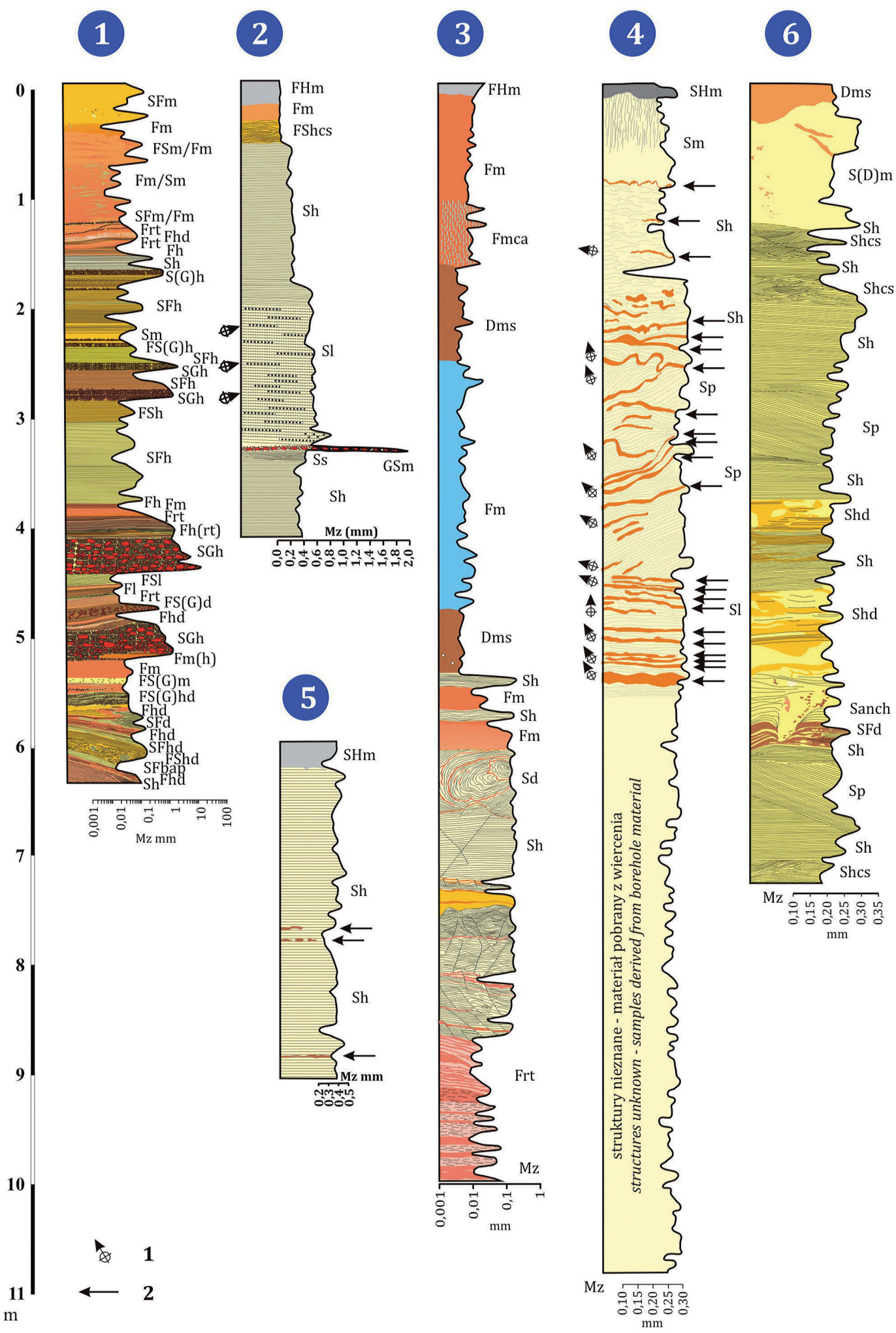

Ryc. 4. Profile litologiczne wybranych odsłonięć w Kotlinach Świeckiej i Grudziądzkiej

D - diamiktony, G - żwiry, S - piaski, H - próchnica, C - wtrącenia węglanowe, F - osady drobnoziarniste (mułki i iły), anch - struktura kotwiczenia brył lodowych, $\mathrm{d}$ - struktura zaburzona, $\mathrm{h}$ - warstwowanie horyzontalne, hcs - warstwowanie kopułowe, 1 - małokątowe warstwowanie przekątne, $\mathrm{m}$ - struktura masywna, $\mathrm{p}$ - warstwowanie przekątne płaskie, $\mathrm{w}$ - laminacja falista, $\mathrm{t}$ - warstwowanie przekątne rynnowe, $\mathrm{rt}$ - heterolityczny rytmit, $\mathrm{s}$ rozmycia wielkoskalowe, $\mathrm{Mz}$ - średnia średnica ziarna, 1 - kierunek upadu lamin, 2 - przewarstwienia diamiktonowe

Fig. 4. Chosen outcrops logs in the Świecie and Grudziądz Basins

$\mathrm{D}$ - diamictons, $\mathrm{G}$ - gravels, $\mathrm{S}$ - sands, $\mathrm{H}$ - humus, $\mathrm{C}$ - calcareous precipitates, $\mathrm{F}$ - fines (silt and clay), anch - anchor structures, $\mathrm{d}$ - disturbed structure, $\mathrm{h}$ - horizontal stratification, hcs - hummocky cross-stratification, $\mathrm{l}$ - low angle cross stratification, $\mathrm{m}$ - massive structure, $\mathrm{p}$ - planar cross stratification, $\mathrm{w}$ - wavy lamination, $\mathrm{t}$ - trough cross stratification, $\mathrm{rt}$ - heterolithic rhytmite, $\mathrm{s}$ - large-scale scour, $\mathrm{Mz}$ - medium grain diameter, 1 - laminae dipping angle, 2 - diamictic intercalations 

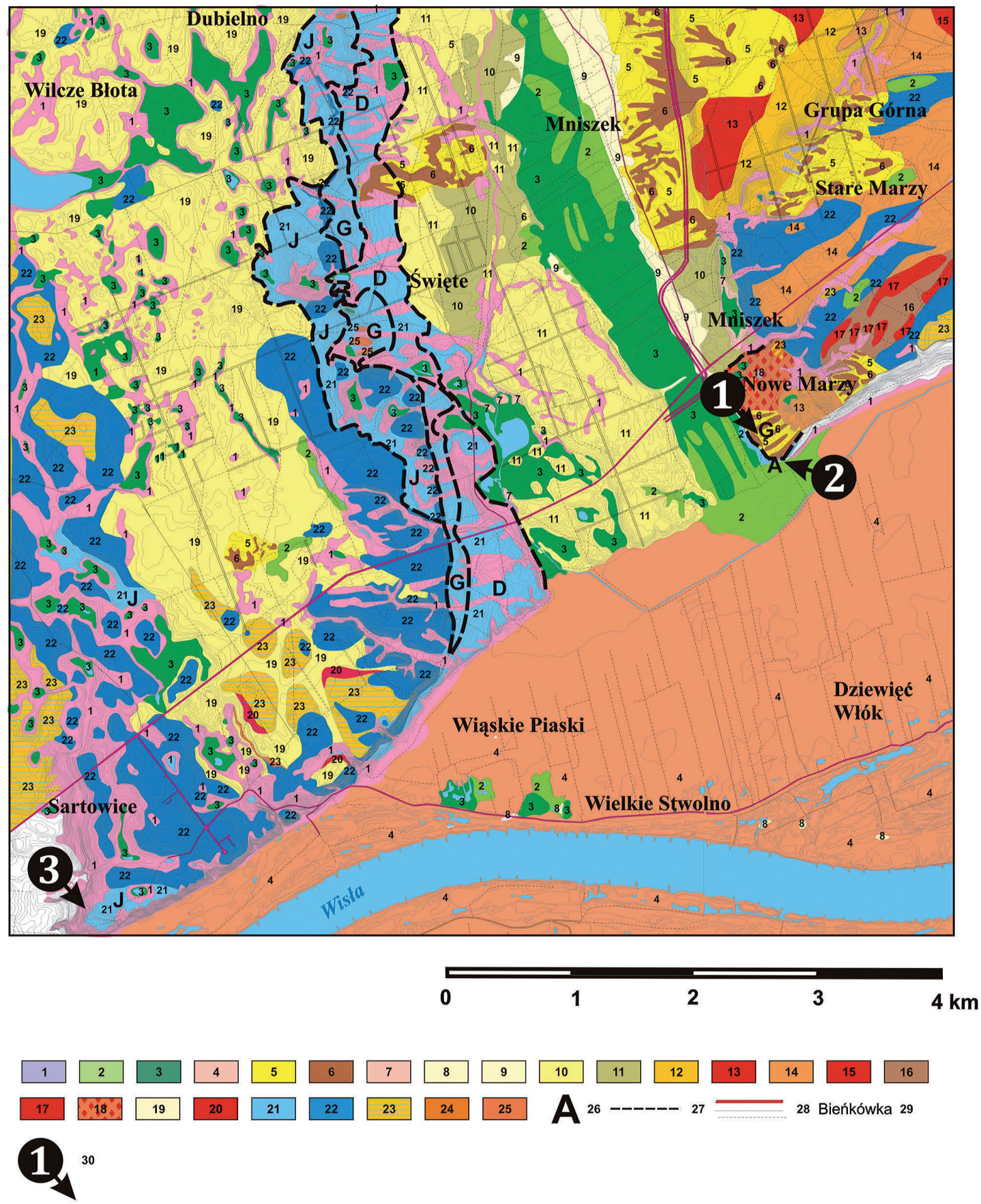

Ryc. 5. Otoczenie geologiczne zastoiska świeckiego

1 - osady stokowe, 2 - namuły, 3 - torfy i gytie, 4 - osady powodziowe, 5 - piaski pokrywowe, 6 - piaski eoliczne w wydmach, 7 - piaski teras jeziornych, 8 - piaski i żwiry korytowe równiny zalewowej Wisły, 9 - piaski i żwiry rzeczne równiny zalewowej Mątawy, 10 - piaski i żwiry rzeczne terasy II, 11 - piaski i żwiry rzeczne terasy III, 12 - piaski rzeczne terasy VIII, 13 - żwiry terasy VIII, 14 - piaski fluwioglacjalne terasy IX, 15 - żwiry terasy IX, 16 - piaski fluwioglacjalne terasy X, 17 - żwiry terasy X, 18 - gliny spływowe, mułki i piaski z domieszką żwirów (spływy gliniaste), 19 - piaski fluwioglacjalne sandru Wdy, 20 - żwiry sandru Wdy, 21 - piaski i mułki glacjolimniczne w terasach kemowych z wkładkami glin spływowych na powierzchni i pod powierzchnią do głębokości $2 \mathrm{~m}, 22$ - iły zastoiskowe na powierzchni i pod powierzchnią do $2 \mathrm{~m}$ głębokości, 23 - piaski, mułki, iły i diamiktony w kemach i starszych terasach kemowych, 24 - górna glina zwałowa, 25 - dolna glina zwałowa, 26 - oznaczenia teras kemowych, 27 - granice teras kemowych, 28 - drogi, 29 - nazwy miejscowości, 30 - odsłonięcia omawiane w tekście

Fig. 5. Geological setting of the Świecie ice dammed lake plain

1 - slope deposits, 2 - organic muds, 3 - peat and gyttja, 4 - floodplain fines, 5 - aeolian sands in covers, 6 - aeolian sands in dunes, 7 - sands of lacustrine terraces, 8 - fluvial channel facies sands and gravels of the Vistula floodplain, 9 - fluvial sands and gravels of Mątawa floodplain, 10 - fluvial sands and gravels of the II-nd terrace, 11 - fluvial sands and gravels of the III-rd terrace, 12 - fluvial sands of the VIII-th terrace, 13 - gravels of the VIII-th terrace, 14 - fluvioglacial sands of the IX-th terrace, 15 - gravels of the IX-th terrace, 16 - fluvioglacial sands of the X-th terrace, 17 - gravels of the X-th terrace, 18 - flow tills, silts and sands, locally with admixture of gravels (debris flows), 19 - fluvioglacial sands of the Wda outwash plain, 20 - outwash plain gravels, 21 - glaciolimnic (kame terraces) sands and silts with flow till intercalations - on surface and subsurface up to $2 \mathrm{~m}, 22$ - glacial clays (ice dammed lake clays) on surface and subsurface up to $2 \mathrm{~m}, 23$ - sands, silts, clays and diamictons of kames and older kame terraces, 24 - upper glacial till, 25 - lower glacial till, 26 - kame terraces levels, 27 - provisional boundaries of kame terraces levels, 28 - roads, 29 - locality names, 30 - outcrops discussed in the text 
udokumentowane w licznych profilach odsłonięć (ryc. 4, odsłonięcia 1, 2, 4, 6).

\section{Zagłębienia wytopiskowe}

Kolejną formą świadczącą o istnieniu form szczelinowych i deglacjacji arealnej Basenu Grudziądzkiego są zagłębienia wytopiskowe. Mają one lokalnie pokrywę glin z wytopienia i glin ablacyjnych. Formy tego typu są powszechnym elementem krajobrazów paraglacjalnych. Ich występowaniu na terasach dolin rzecznych dolnej Wisły nie poświęcano jednak zbyt wiele uwagi. Zagłębienia te mają czasami znaczne rozmiary. Największe występują w Basenie Unisławskim (Kordowski 2001), gdzie jedna

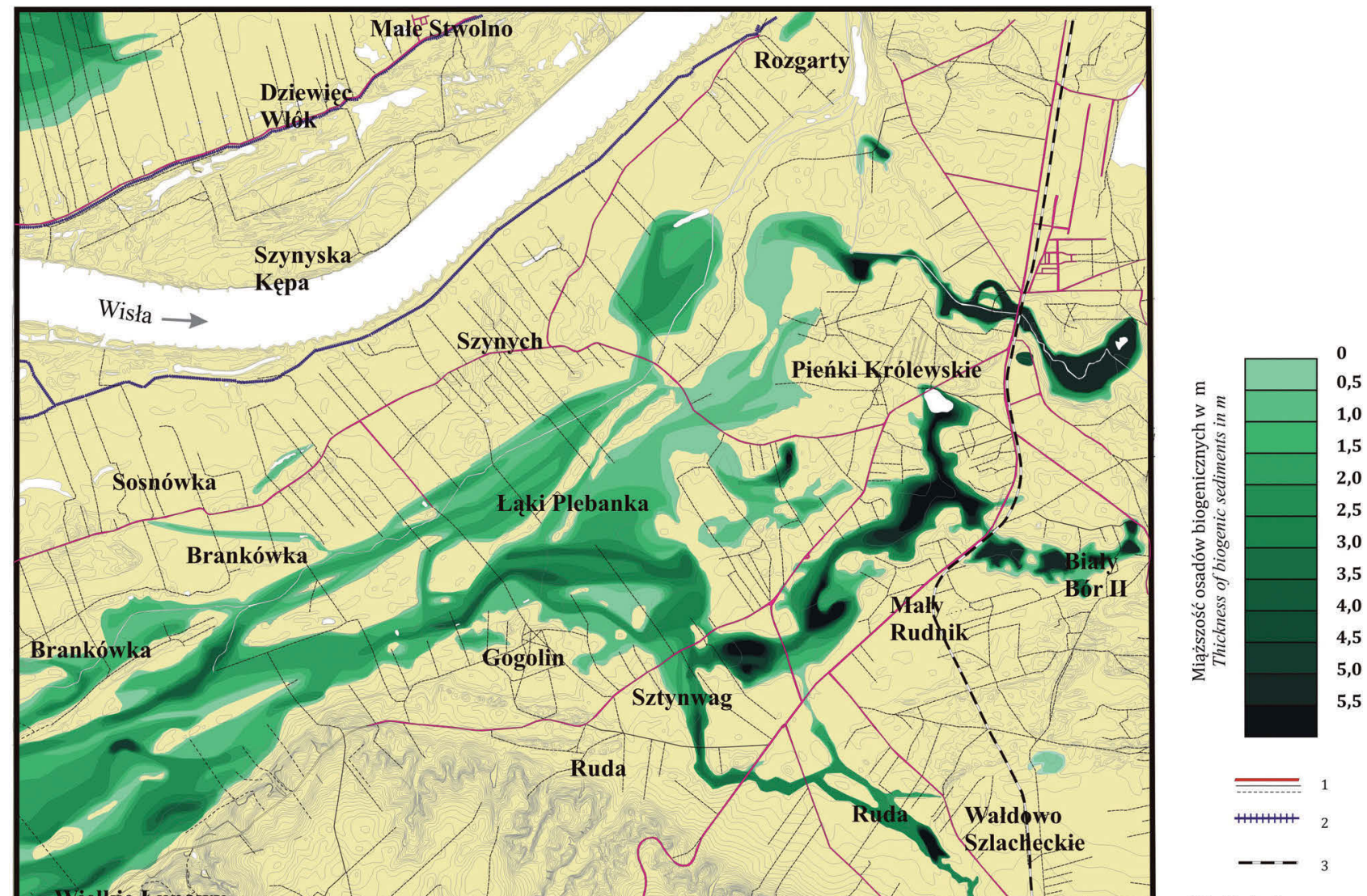

Bieńkówka 4

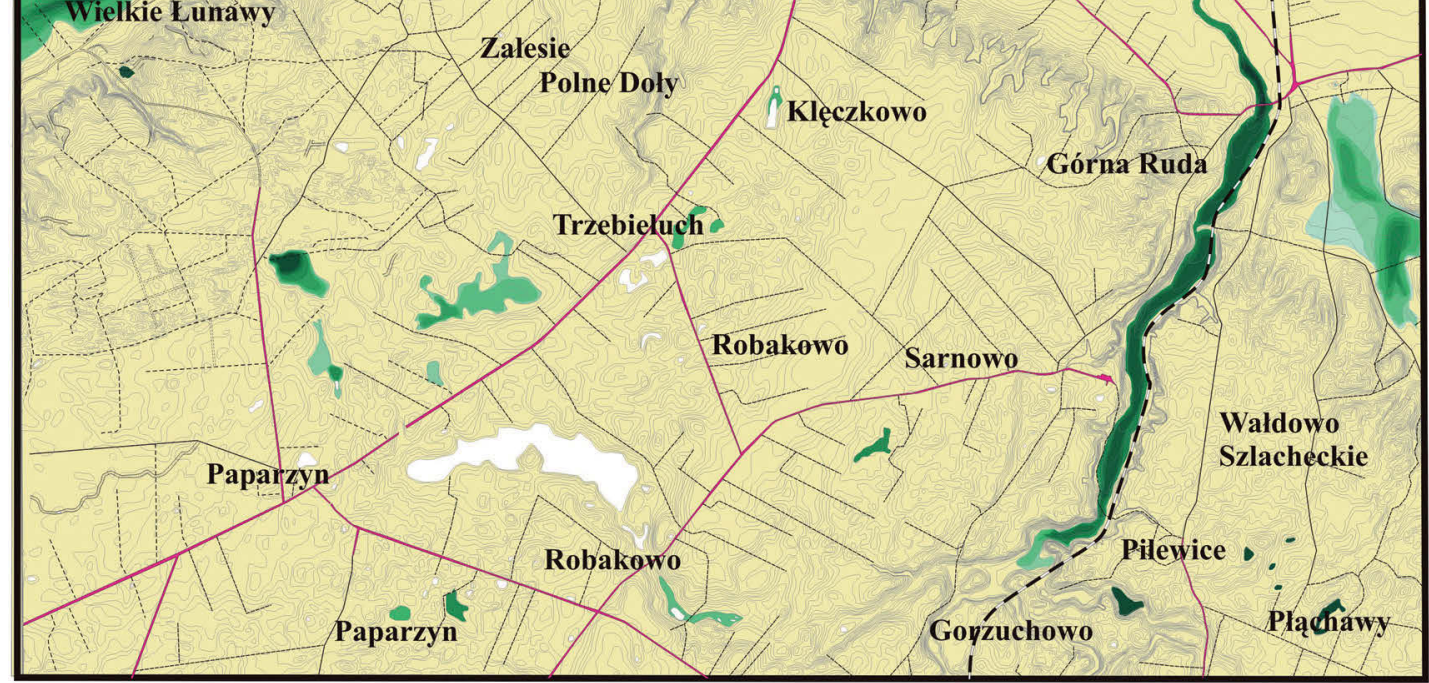

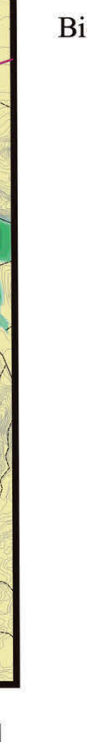

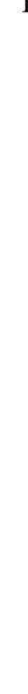

$4 \mathbf{k m}$

Ryc. 6. Mapa miąższości osadów biogenicznych w południowej części Kotliny Grudziądzkiej

1 - drogi, 2 - wały przeciwpowodziowe, 3 - linie kolejowe, 4 - nazwy miejscowości

Fig. 6. Map of thickness of biogenic sediments in the southern part of Grudziądz Basin

1 - roads, 2 - embankments, 3 - railways, 4 - localities 
z form ma ponad $5 \mathrm{~km}$ długości i 2-3 km szerokości. Wypełnione są obecnie gytiami i torfami o miąższości do 10 m (Niewiarowski 1987).

Podobnie rzecz ma się w południowej części Kotliny Grudziądzkiej (ryc. 6). Największą formą wytopiskową jest tam Jezioro Rudnickie o średnicy do $2 \mathrm{~km}$. Kotły wytopiskowe występują tu głównie na linii współczesnych dolin Młynkówki i Rudniczanki. Osiagają one do kilkuset metrów średnicy i kilku metrów głębokości. Obecnie wypełniane są torfami i gytiami. W otoczeniu niektórych wytopisk stwierdzone zostały w wierceniach osady morenowe, występujące w postaci stref o szerokości od kilku do kilkunastu metrów. Osady te powstały w efekcie wytopienia brył martwego lodu i są obserwowane w wierceniach do głębokości co najmniej $2 \mathrm{~m}$.

\section{Ostańce terasowe}

Kolejnym elementem rzeźby powstałym w efekcie degradacji brył martwego lodu są ostańce terasowe (ryc. 3). Są to formy o średnicy kilkuset metrów i wysokości kilku metrów. Formy te są otoczone przez wytopiska. Bryły martwego lodu o różnych rozmiarach, tkwiące w osadzie chroniły przed rozmyciem fragmenty starszych teras. Ostańce terasowe od powierzchni zbudowane są z piasków różnoziarnistych $\mathrm{z}$ domieszką żwirów. Obecność brył lodu w czasie depozycji osadów najniższych poziomów terasowych świadczy o przebiegu procesu kształtowania teras, znacznie szybszym niż tempo wytapiania brył martwego lodu. Odsłonięte bryły martwego lodu ulegają bowiem szybkiemu wytapianiu w skali kilkudziesięciu do niewielu setek lat (Washburn 1979).

\section{Rynny subglacjalne}

Kolejnym dowodem świadczącym o obecności brył martwego lodu w Dolinie Dolnej Wisły są reprodukowane rynny subglacjalne. Proces reprodukcji tych form polegał na odtworzeniu przebiegu rynny w osadach fluwialnych i fluwioglacjalnych, które wypełniły pierwotną formę zaraz po jej powstaniu. Rynny subglacjalne są miejscem, gdzie istnieją sprzyjające warunki do nieco dłuższego, niż w ich otoczeniu zalegania brył stagnującego i martwego lodu. Po ich wytopieniu powstawały podłużne wytopiska, które odtwarzały zarysy przebiegu rynny. Formą taką jest rynna fletnowska, rozpoczynająca się w południowej części Pojezierza Starogardzkiego i ciągnąca się na niemal wszystkich poziomach terasowych w zachodniej części Kotliny Grudziądzkiej, gdzie tworzy ją łańcuch zagłębień o łącznej długości około $10 \mathrm{~km}$. Szerokość tych form wynosi 100-300 m, zaś głębokość sięga $30 \mathrm{~m}$. Są one wypełnione głównie deluwiami, a w najniższych poziomach terasowych torfami i gytiami badanymi w rejonie Fletnowa przez Kępczyńskiego i Noryśkiewicz (1968). Obecność ciągu wytopisk, które wyznaczają dawny zasięg rynny subglacjalnej, wyraźnie wskazuje, że depozycja fluwialna i fluwioglacjalna w tej części Kotliny Grudziądzkiej odbywała się nad bryłami lodu.

\section{Osady zastoiskowe}

Osady zastoiskowe deponowane w dolinie rzecznej nie muszą świadczyć o obecności brył martwego lodu. W przypadku zastoiska świeckiego są one włożone jednak w formę dolinną (ryc. 5).

Seria glacjolimniczna ma około 5,5 m miąższości, przy czym osady iłów zastoiskowych zajmują tylko około $2,5 \mathrm{~m}$, resztę stanowią różnego typu osady spływowe (ryc. 4, stanowisko 3). W dolnej części profilu stwierdzono osady litologicznie zbliżone do osadów budujących terasy kemowe udokumentowane w odsłonięciach 1, 4 i 6 (ryc. 4). Są one w części zaburzone grawitacyjnie, bowiem występują w nich fałdy obalone i uskoki komplementarne powstające wskutek narastającego obciążania następnymi utworami akumulowanymi nad nimi. Jak na razie nie ma przekonujących dowodów na ewentualne zaburzenia glacitektoniczne tych osadów. Występują tu piaski warstwowane horyzontalnie, rytmity składające się z lamin mułku ilastego i mułku piaszczystego oraz lamin piasków średnioziarnistych i drobnoziarnistych z akcesorycznymi wkładkami masywnych mułków deponowanych w czasie zaprzestania przepływu. Biorąc pod uwagę omówione wcześniej terasy kemowe, istnieją podstawy do przyjęcia, że osady w tym odsłonięciu powstały w warunkach podparcia lodowego. Kwestią wymagającą dalszych badań jest relacja omówionych osadów do wstęg gliniastych w dnie doliny, ponieważ jak dotąd rozpoznane zostały one tylko w wierceniach.

\section{Wnioski}

Formy wiązane ze środowiskiem glacilimnicznym występują w bardzo wysokich oraz niskich położeniach geomorfologicznych, np. w poziomie równiny zalewowej. Bryły martwego lodu wpływały na rozwój całego systemu terasowego $\mathrm{z}$ wyjątkiem równiny zalewowej (Kordowski 2010). Fakt ten wyraźnie komplikuje interpretację rozwoju paleogeograficznego doliny Wisły (por. Kordowski 2005), dopuszczając i po części wyjaśniając nieciągłość wielu poziomów morfologicznych (w tym terasowych), bo niekiedy związanych $\mathrm{z}$ wytapianiem brył lodu (spływy grawitacyjne glin morenowych), a nie $\mathrm{z}$ działalnością fluwioglacjalną wód lodowcowych lub fluwialną Wisły. Obecność rozległych płatów martwego lodu wskazywałaby też na to, że ukształtowanie się dużych fragmentów doliny nastąpiło jeszcze przed ostatnim nasunięciem lądolodu w fazie poznańskiej. Drozdowski (1974) uważał, że martwe lody mogły tu przetrwać jeszcze od czasu stadiału świecia. Ostatnio pojawiła się jednak możliwość ich przetrwania od czasu nasunięcia fazy przedmaksymalnej (30-32 ka BP) stadiału głównego (Weckwerth i in. 2011, Marks 2012, Weckwerth 2013) lub z fazy leszczyńskiej ostatniego zlodowacenia (Wysota, Molewski 2011), kiedy to żywy fragment lobu Wisły cofnął się na północ od Świecia, by ponownie nasunąć się na linię maksymalnego postoju w lobie Wisły 
w czasie fazy poznańskiej. Kwestia ta wymaga jednak dalszych badań.

Początek rozwoju teras kemowych w Kotlinie Grudziądzkiej wiązał się z wypełnianiem szczelin lodowych glinami spływowymi w niższych pozycjach morfologicznych, zaś w wyższych gruboziarnistą depozycją facji żwirów masywnych i warstwowanych poziomo, która stop-
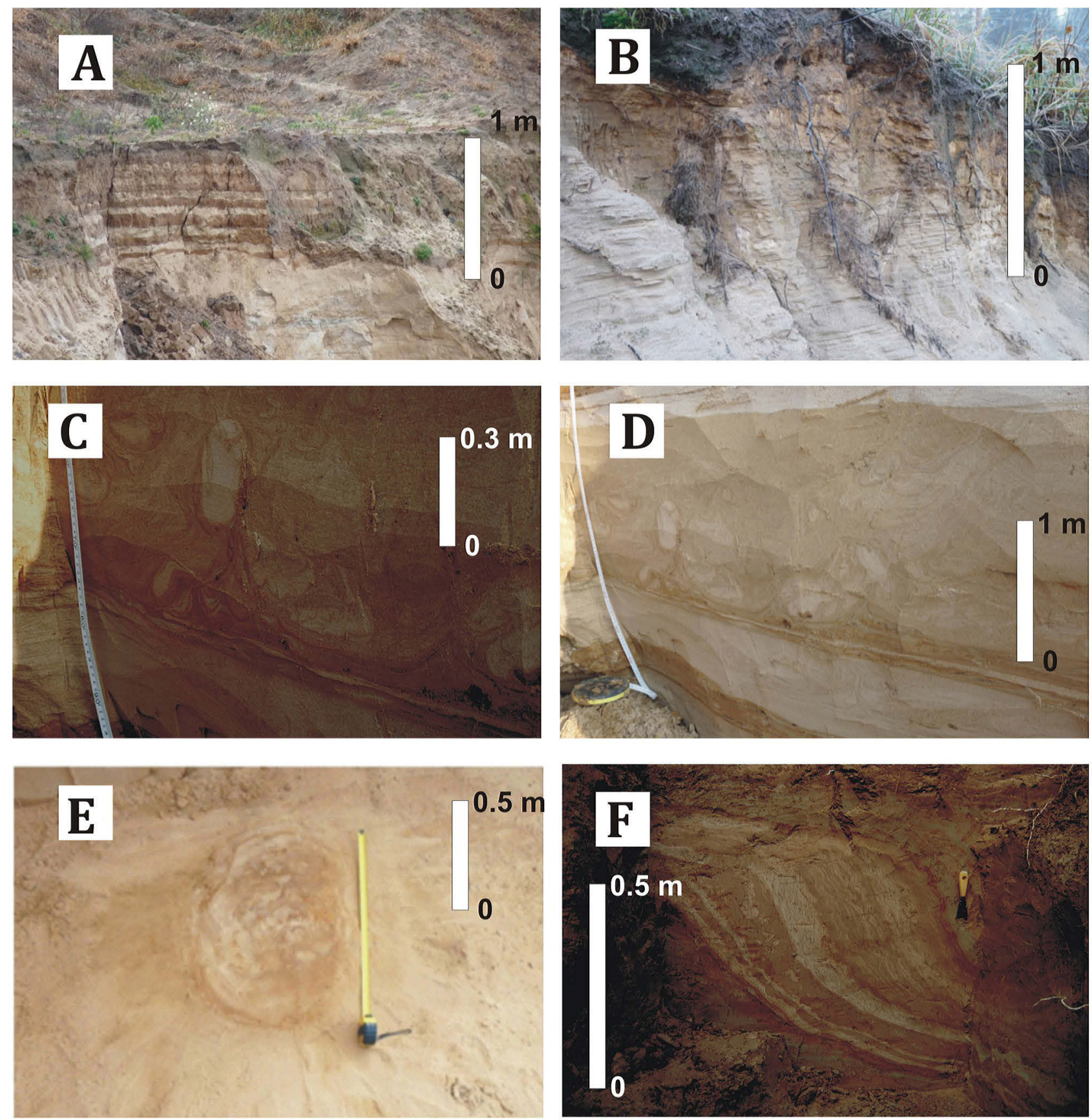

Ryc. 7. Wybrane struktury sedymentacyjne osadów wiązane z obecnością brył martwego lodu

A - rytmit piaszczysto-diamiktonowy na najniższej terasie kemowej wysokościowo odpowiadającej pierwszej terasie nadzalewowej, B - dominująca litofacja teras kemowych, warstwowanie horyzontalne, odsłonięcie $6, \mathrm{C}, \mathrm{D}$ - struktury piłeczkowo-poduszkowe w odsłonięciu 1, E - bryła gliniasta w osadach piaszczystych w Górze Zamkowej w Grudziądzu interpretowana jako przytransportowana przez górę lodową, F - osady wypełnienia niecki powstałej w wyniku powolnego wytapiania napławionej bryły lodu w spągowej części odsłonięcia 3

Fig. 7. Selected sedimentary structures in sediments associated with the presence of dead ice blocks

A - sandy-silty rhytmite on the surface of the lowest kame terrace which corresponds to the altitude of the I-st terrace above the floodplain level, B dominating lithofacies of kame terraces sediments, horizontal lamination, outcrop $6, \mathrm{C}, \mathrm{D}$ - ball and pillow structures within the outcrop 1, E- dumped till block in sandy sediments of Góra Zamkowa in Grudziądz interpreted as delivered by the iceberg, F - small hollow originated due to slow thawing of small grounded ice block in bottom part of the outcrop 3 
dominacja struktur horyzontalnych w osadach piaszczystych związanych $\mathrm{z}$ wysokoenergetycznymi zalewami warstwowymi. Dominacja warstwowania horyzontalnego upodabnia omawiane osady do środkowovistuliańskiej serii rzecznej z Rzęczkowa (Wysota i in. 1996, Wysota 2002). Zdaniem autora wiele cech, takich jak obecność laminacji z dropstone'ami, warstw masywnych mułków, powszechność występowania cienkich wkładek gliniastych w piaskach warstwowanych horyzontalnie (ryc. 4, odsłonięcia 1, 4 i 6), obecność brył gliniastych zrzuconych z gór lodowych (ang. dump structures) (ryc. 7E) oraz osady wypełnienia drobnych niecek z wytapiania napławionych brył lodowych (ryc. 7F, spągowa część odsłonięcia 3 na ryc. 4, $10 \mathrm{~m}$ od powierzchni terenu), pozwala wysnuć wniosek, że osady te deponowane były w zbiornikach wodnych o zmiennej powierzchni i głębokości, pomiędzy krawędzią wysoczyzny a bryłami lodu wypełniającymi Kotlinę Grudziądzką. Dowodzi tego także obecność struktur poduszkowo-piłeczkowych (ryc. 7C, D, spągowa część odsłonięcia 1 na ryc. 4) oraz miąższych pakietów piasków masywnych. Powstały one najprawdopodobniej w wyniku uwodnienia osadów i rozwoju osuwisk podwodnych wskutek podnoszenia się poziomu wody.

\section{Podziękowania}

Część materiałów do niniejszego opracowania zebrana została w trakcie realizacji grantu Ministerstwa Nauki i Szkolnictwa Wyższego nr NN 306289635 „Morfogeneza Kotliny Grudziądzkiej w świetle analizy osadów i rzeźby doliny Wisły oraz obszarów przyległych". Kontynuacja prac była możliwa dzięki projektowi ICLEA (www.iclea.de). [This is a contribution to ICLEA (Virtual Institute for Integrated Climate and Landscape Evolution Analyses) of the Helmholtz Association]. Część badań sfinansowana została dzięki dotacji Zarządu Województwa Kujawsko-Pomorskiego w sezonie 2007. Wykonanie wielu prac nie byłoby możliwe bez zgody na prace geologiczne ze strony nadleśnictw w Dąbrowie koło Jeżewa oraz Jamy koło Grudziądza. Firmie Skanska NDi dziękuję uprzejmie za udzielenie zgody na poruszanie się i dokumentowanie odsłonięć na trasie budowanej autostrady A1 w Kotlinie Grudziądzkiej. Panom dr. hab. Marcinowi Wiewiórze i mgr. Michałowi Majewskiemu dziękuję za możliwość obserwacji struktur sedymentacyjnych osadów w wykopach archeologicznych w Górze Zamkowej w Grudziądzu. Anonimowym Recenzentom i Redaktorom tomu dziękuję za trud recenzji i ulepszenia artykułu.

\section{Literatura}

Berglund B.E., Drozdowski E., 1976. Development and chronology of the lower Vistula River valley. Boreas 5: 95-107.

Bitinas A., Karmaziene D., Jusiene A., 2004. Glaciolacustrine kame terraces as an indicator of conditions of deglaciation in Lithuania during the Last Glaciation. Sedimentary Geology 165(3-4): 285-294.
Błaszkiewicz M., 2005. Późnoglacjalna i holoceńska ewolucja obniżeń jeziornych na Pojezierzu Kociewskim (wschodnia część Pomorza). Prace Geograficzne 201.

Butrymowicz N., 1981. Szczegółowa mapa geologiczna Polski 1:50 000, arkusz Chełmno. Wydawnictwa Geologiczne, Warszawa.

Chormański J., Mycielska-Dowgiałło E., 1996. Ewolucja doliny Wisły od Kępy Płockiej do Płocka w okresie ostatniego zlodowacenia i holocenu. W: Z. Mikulski, E. Bajkiewicz-Grabowska (red.), Ekologiczne podstawy zagospodarowania dolin rzecznych (na przykładzie Wisły pod Płockiem), Towarzystwo Naukowe Warszawskie, Uniwersytet Warszawski, Wydział Geografii i Studiów Regionalnych, Warszawa: 97-112.

Drozdowski E., 1974. Geneza Basenu Grudziądzkiego w świetle osadów i form glacjalnych. Prace Geograficzne 104.

Drozdowski E., 1979. Deglacjacja dolnego Powiśla w środkowym würmie i związane z nią środowiska depozycji osadów. Prace Geograficzne 132

Drozdowski E., 1982. The evolution of the lower Vistula river valley between the Chełmno Basin and the Grudziądz Basin. W: L. Starkel (red.), Evolution of the Vistula river valley during the last 15000 years. Geographical Studies, Special Issue: 131-147.

Flint R.F., 1971. Glacial and Quaternary geology. Wiley, New York.

Folk R.L., Ward W.C., 1957. Brazos River bar: a study in the significance of grain size parameters. Journal of Sedimentary Research 27: 3-26.

Galon R., 1934. Dolina dolnej Wisły, jej kształt i rozwój na tle budowy dolnego Powiśla. Badania Geograficzne Polski Północno-Zachodniej $12-13$.

Galon R., 1953. Morfologia sandru i doliny Brdy. Studia Societatis Scientiarum Torunensis. C, Geographia et Geologia 1(6).

Galon R., 1961. Morphology of the Noteć-Warta (or Torun-Eberswalde) ice marginal streamway. Prace Geograficzne 29.

Galon R., 1968. New facts and problems pertaining to the origin of the Noteć-Warta pradolina and the valleys linked with it. Przegląd Geograficzny 40(4): 307-315.

Karczewski A., 1971. Zmienność litologiczna kemów Pomorza Zachodniego a zagadnienie ich klasyfikacji. Prace Komisji Geograficzno-Geologicznej, Poznańskie Towarzystwo Przyjaciół Nauk 11(3): $3-57$.

Kępczyński K., Noryśkiewicz B., 1968. Roślinność i historia torfowiska Fletnowo w pow. grudziądzkim. Zeszyty Naukowe Uniwersytetu Mikołaja Kopernika, Nauki Matematyczno-Przyrodnicze 21, Biologia XI: 49-95.

Klimaszewski M., 1981. Geomorfologia. Wydawnictwo Naukowe PWN, Warszawa.

Kordowski J., 2001. Rola martwego lodu w kształtowaniu rzeźby Basenu Unisławskiego. Przegląd Geologiczny 49(10/1): 918-922.

Kordowski J., 2005. Problemy interpretacji rzeźby dna Doliny Dolnej Wisły w Basenie Świeckim w świetle ostatnich badań geomorfologicznych. Przeglad Geograficzny 77(3): 343-355.

Kordowski J., 2010. Geomorphological and sedimentological indicators of early stage anostomosing in the lower Vistula River valley, north central Poland, prior to recent river regulation. W: S. Lorenz, R. Lampe (red.), Gletscher, Wasser, Mensch - quartärer Landschaftswandel im peribaltischer Raum. 35. Hauptversammlung der Deutschen Quartaervereinigung DEUQUA E.V. 12th Annual Meeting of the INQUA Peribaltic Working Group., 13.-17. September 2010 in Greifswald. Tagungsunterlagen. Lehrstuhl Physiche Geographie. Institut für Geographie und Geologie, Universitaet Greifswald, Greifswald: 38-39.

Kordowski J., 2013. The role of blocks of dead ice in the deposition of late glacial sediments in a large valley: A case study from the Vistula river valley in the Grudziądz Basin, north Poland. Geographia Polonica 86(4): 341-361.

Kordowski J., Tyszkowski S., Bienias D., 2012. Budowa geologiczna i przekształcenia Góry Zamkowej i jej otoczenia. W: M. Wiewióra (red.), Zamek w Grudziądzu w świetle badań archeologiczno-architektonicznych. Studia i materiały. Wydawnictwo Naukowe Uniwersytetu Mikołaja Kopernika, Toruń: 29-47.

Kordowski J., Błaszkiewicz M., Kramkowski M., Tyszkowski S., Brauer A., Brykała D., Gierszewski P., Lamparski P., Lutyńska M., Mirosław-Grabowska J., Noryśkiewicz A.M., Obremska M, Ott F., Słowiński M., Wulf S., Zawiska I., 2014. Ewolucja misy Jeziora Cze- 
chowskiego (Pojezierze Stargardzkie) w świetle analiz osadów jego otoczenia. Landform Analysis, ten tom.

Maksiak S., 1983. Szczegółowa mapa geologiczna Polski 1:50 000, arkusz Grudziądz-Rudnik. Wydawnictwa Geologiczne, Warszawa.

Marks L., 2012. Timing of othe Late Vistulian (Weichselian) glacial phases in Poland. Quaternary Science Reviews 44: 81-88.

Molewski P., 2007. Neotektoniczne i glacidynamiczne uwarunkowania wykształcenia plejstocenu wysoczyzny kujawskiej. Wydawnictwo Naukowe Uniwersytetu Mikołaja Kopernika, Toruń.

Niewiarowski W., 1961. Types of kames occuring within the area of the last glaciation compared with kames known from other regions. International Association of Quaternary Research, Report of the International Congress on Quaternary III, Łódź: 475-485.

Niewiarowski W., 1968. Morfologia i rozwój pradoliny i doliny dolnej Drwęcy. Studia Societatis Scientiarum Torunensis, C, Geographia et Geologia 6(6).

Niewiarowski W., 1987. Evolution of the lower Vistula valley in the Unisław Basin and the river gap to the North of Bydgoszcz Fordon. W: L. Starkel (red.), Evolution of the Vistula River Valley during the last 15,000 years. Geogr. Studies, Special Issue 4(2): 234-252.

Skompski S., 1969. Stratygrafia osadów czwartorzędowych we wschodniej części Kotliny Płockiej. Z badań czwartorzędu w Polsce 12. Biuletyn PIG 220: 175-258.

Sonntag P., 1919. Geologie von Westpreußen. Verlag von Gebrüder Borntraeger, Berlin.

Washburn A.L., 1979. Geocryology. A survey of periglacial processes and environments. Edward Arnold (Publishers) Ltd, London.

Weckwerth P., 2006. Problem bifurkacji Wisły pod Fordonem (Bydgoszcz) na tle ewolucji Kotliny Toruńskiej pod koniec plenivistulianu. Przegląd Geograficzny 78(1): 47-68.
Weckwerth P., 2010. Evolution of the Torun Basin in the Late Weichselian. Landform Analysis 14: 57-84.

Weckwerth P., 2013. Ewolucja fluwialnych systemów depozycyjnych i jej uwarunkowania paleośrodowiskowe w Kotlinie Toruńskiej podczas zlodowacenia wisły. Wydawnictwo Naukowe Uniwersytetu Mikołaja Kopernika, Torun.

Weckwerth P., Przegiętka K., Chruścińska A., Woronko B., Oczkowski H.L., 2011. Age and sedimentological features of fluvial series in the Toruń Basin and the Drwęca Valley (Poland). Geochronometria 38: 397-412.

Wiśniewski E., 1990. Evolution of the Vistula Valley. W: L. Starkel (red.), Evolution of the Vistula River valley during the last 15000 years. Pt. III, Geographical Studies, Special Issue 5: 141-146.

Wysota W., 2002. Stratygrafia i środowiska sedymentacji zlodowacenia wisły w południowej części dolnego Powiśla. Wyd. Uniwersytetu M. Kopernika w Toruniu. Rozprawa habilitacyjna.

Wysota W., Lankauf K.R., Molewski P., Szmańda J., 1996. Sedymentologia interstadialnej serii rzecznej (Rzęczkowo) zlodowacenia Wisły (Vistulian) odsłoniętej w SW krawędzi Wysoczyzny Chełmińskiej. Acta Universitatis Nicolai Copernici, Geographia 28: 39-63.

Wysota W., Molewski P., 2011. Chronologia i zasięgi nasunięć lądolodu na obszarze lobu Wisły podczas stadiału głównego ostatniego zlodowacenia. Przegląd Geologiczny 59(3): 214-225.

Zieliński T., 1998. Litofacjalna identyfikacja osadów rzecznych. W: E. Mycielska-Dowgiałło (red.), Struktury sedymentacyjne i postsedymentacyjne i ich wartość interpretacyjna. Wydział Geografii i Studiów Regionalnych Uniwersytetu Warszawskiego, Warszawa: 195-257. 